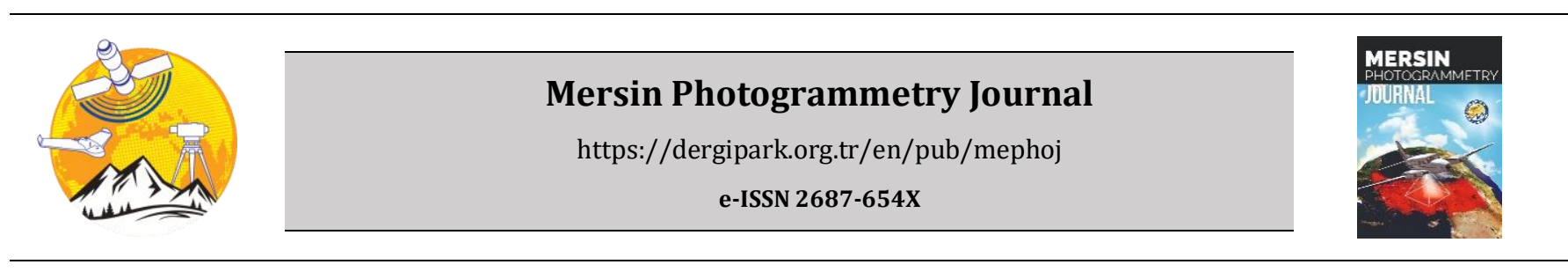

\title{
Documenting historical monuments using smartphones: a case study of Fakih Dede Tomb, Konya
}

\author{
Mustafa Emre Döş̧ ${ }^{\oplus}$ Abdurahman Yasin Yiğit ${ }^{*} @$, Murat Uysal ${ }^{3} @$ \\ ${ }^{1}$ Hatay Mustafa Kemal University, Antakya Vocational School/Department of Architecture and Urban Planning, Hatay, Turkey \\ 2 Mersin University, Faculty of Engineering, Geomatics Engineering, Mersin, Turkey \\ ${ }^{3}$ Afyon Kocatepe University, Engineering Faculty, Department of Geomatics Engineering, Afyonkarahisar, Turkey
}

\author{
Keywords \\ Photogrammetry \\ Modelling \\ Historical Monuments \\ SFM \\ Smartphones
}

\begin{abstract}
Cultural heritage and historical monuments are the memories of societies and enable future generations to learn about the past. However, historical monuments from the past to the present have been subjected to many destructions, natural or unnatural. Thanks to advances in technology, it is easier to document historical monuments using digital photogrammetric methods. Today, we see the methods used in documenting historical artifacts as traditional measurement, laser scanning, and photogrammetric methods or combinations of them. In this study, historical artifacts were tried to be documented through close-up photogrammetry methods, which is a sub-working area of photogrammetry, through images taken with nonmetric cameras of smartphones that we use frequently in our daily lives. Planned geodesic measurement and photography should be done in order to perform three-dimensional (3D) modeling with close-up photogrammetry. During the study, the checkpoints were measured using geodesic methods on the historical monument and part of it was reserved for accuracy analysis. The tomb of Fakih Dede in Konya, which is an important point of visit in the region has been chosen.
\end{abstract}

\section{Introduction}

Cultural heritage has taken an important place in the culture and creativity of a society. Cultural heritages can be classified as public goods with their features (Yılmaz et al., 2000; Korumaz et al., 2011). Cultural and heritage properties provide certain benefits to the areas in which they are located, although there are not enough public resources for their maintenance and protection (Yakar et al., 2005; Alptekin et al., 2020; Polat et al., 2021a). Culture not only promotes economic development but can also be used as a means of transforming certain geographical areas. It, therefore, forms part of many local and regional economic development strategies (Alptekin et al., 2019; Polat et al., 2021b). Unfortunately, historical artifacts have been exposed to aging, humidity, dust, pressure, etc. over the years. They are exposed to irreversible deformation and damage caused by human beings as well as physical factors caused by the natural environment (Castellini et al., 2008; Lopez-Aparicio and Grašiene, 2013; VarasMuriel et al. et al., 2014). Therefore, historical artifacts must be documented in order to be passed on to future generations. Documentation studies can form the basis for restoration projects of historical artifacts that have undergone deformation (Şenol et al., 2021).

Up-to-date and accurate information about architectural and structural features, geometric shapes, and materials are the most important bases for the restoration of historical monuments (Yakar et al. 2010). However, the original architectural drawings necessary for the restoration of historical monuments cannot be found or are of low quality. Therefore, it is vital to document historical artifacts and monitor their displacement and deformation (Şenol et al., 2020; Kaya et al., 2021; Sužiedelytė-Visockienè et al., 2015). The measurement of a structure with traditional methods is a costly and time-consuming task. Especially the high 
parts of the structure are more difficult to access and measure. For this purpose, remote sensing and photogrammetric methods can be used (Ozimek et al., 2021; Yakar et al. 2015). The photogrammetry technique stands out as the most used technique, especially since it allows to the production of threedimensional (3D) models from two-dimensional (2D) photographs taken with non-metric cameras.

Today, in the production of a 3D model, it is mainly obtained from active or passive sensors, which are noncontact systems based on light waves. We can currently distinguish four alternative methods for object and scene modeling:

- Image-Based Rendering is a preferred technique for rendering virtual views, which does not involve the creation of a geometric 3D model;

- Image-Based Modeling (e.g., photogrammetry), a commonly used method for geometric surfaces of architectural objects, precision terrain, and city modeling, and Cultural Heritage documents;

- $\quad$ Range Based Modeling (eg laser scanning) is also very common for non-expert users such as cultural heritage professionals;

- The combination of Image and Range Based Modeling, where both have advantages and disadvantages, and their integration can allow efficient and rapid generation of complete and detailed 3D models (Guarnieri et al., 2006).

More recently, experts in the documentation of cultural heritages have focused on the application of photogrammetric reconstruction, the documentation of historical artifacts (Di Angelo et al., 2021; Apollonio et al., 2021), and the documentation of complex buildings (Reinoso-Gordo et al., 2021; Donato et al. et al., 2019) have worked in many areas, from the documentation of historical landscape fragments (Bruha et al., 2020).

The integration of laser scanning technology and digital image photogrammetry enables the 3D digitization of architectural structures and elements. In this way, digital documentation and spatial information can be continuously monitored at different time intervals (Alkheder et al., 2009; Remondino, 2011; Pesci et al., 2013; Tapete et al., 2013). It creates a set of data points that can be converted into $3 \mathrm{D}$ point clouds required for the creation of $2 \mathrm{D}$ or $3 \mathrm{D}$ models with both technologies (Akman et al., 2010; Gruen and Akca, 2005; Yastikli et al., 2007). Although obtaining point cloud data using laser scanning is a faster technique, photogrammetric methods come to the fore due to their advantages such as affordability, limited accessibility of indoor building areas, limited portability, special expertise required, and other factors (Arias et al., 2006). ; Chandler et al., 2007; Martínez etal., 2013; SužiedelyteVisockiene et al., 2011).

These advantages of photogrammetry technology are based on the ability to work with newly developed algorithms. Photogrammetry, which has developed methodologically, has also been developed as data collection material. The first of these is the use of nonmetric cameras. Thanks to the integration of non-metric cameras into smartphones, the photographic data obtained has become usable in photogrammetric evaluation. With the use of smartphones in this area, access to data collection tools has reached a high level. With the development of data collection materials, many people have started to use the photogrammetry technique with the photographic data obtained on smartphones and interesting results have emerged. Especially amateur users have found a place for themselves in a scientific study with the integration of photogrammetry technique with non-metric cameras without being aware of it.

In this study, images were taken with non-metric In this study, images were taken with non-metric cameras of smartphones, which we frequently use in our daily life, and a different study was carried out on the documentation of historical artifacts with the closerange photogrammetry method over these images. In the second part of the article, the results obtained from the field of study, the methods and materials used in the third part, and the results obtained in the fourth part are presented and finally, the results are discussed.

\section{Study area}

During the Karamanoğulları Principality period, the most important settlement area stands out as Konya. The political and cultural relations of the Karamanids and the Anatolian Seljuks began with the siege of Konya by Karamanoğlu Mehmed Bey in 1277. The urbanization activities of the Karamanoğulları Principality, which had an independent existence since the beginning of the 14 th century, coincided with the first half of the 15th century. Urbanization activities in this process continued first in Ermenek, then in the centrum of Karaman and Konya. Karamanoğulları structures in Konya consist of small-sized mosques, tombs, darülhüffaz (the institution that trains Hafiz), and Turkish baths. According to the inscription of the Konya Ahmed Fakih Tomb, which constitutes our work, it was built in 1456 for Şeyh Fakih Pasha, the son of Isa. The tomb is located in the Karatay district of Konya province today. The mausoleum is structurally square prism type and has a single story. The structure is similar to Seljuk structures with a dome from the inside and an octagonal pyramidal cone/double-layered cover system from the outside. The tomb draws attention with the use of rubble, cut stone, brick, spolia, and tiles (Şaman-Doğan, 2009).

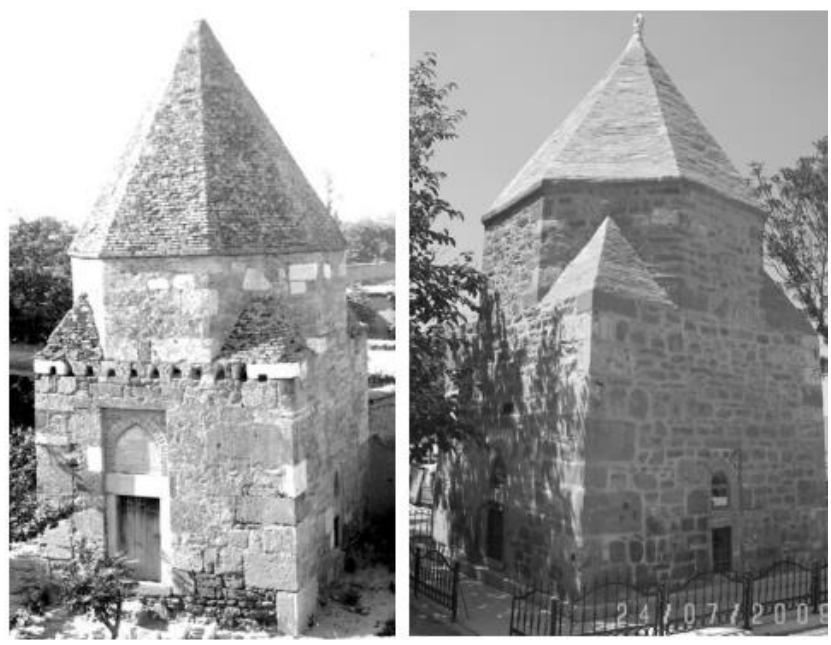

Figure 1. Fakih Dede Tomb north and south facade view 


\section{Material and method}

Across studies, the use of a single stereo pair may be insufficient to reconstruct the complex structures of historic buildings. For this reason, almost all (80\%) photographs should be used to cover the target object as a whole. Care should be taken to ensure regularity in selecting observation points and ensuring a conflict in the form of repeated photo coverage for at least $60 \%$ of the area of adjacent frames. Observations have shown that the optimal displacement angle between the sequential squares of the sequence is approximately 100-15o when sensing the object from a circular orbit surrounding it (Asri \& Çorumluoğlu, 2007; Skabek and Tomaka, 2014). This helps to improve accuracy when using images of a camera (smartphones) whose internal router is unknown or not calibrated. Therefore, bundle adjustment is a wide-spreading technique in today's terrestrial photogrammetry (Figure 2). Combines the application of semi-metric or even non-metric cameras, convergent photos, and flexible measurements in a common computer environment (Kuçak et al., 2016).
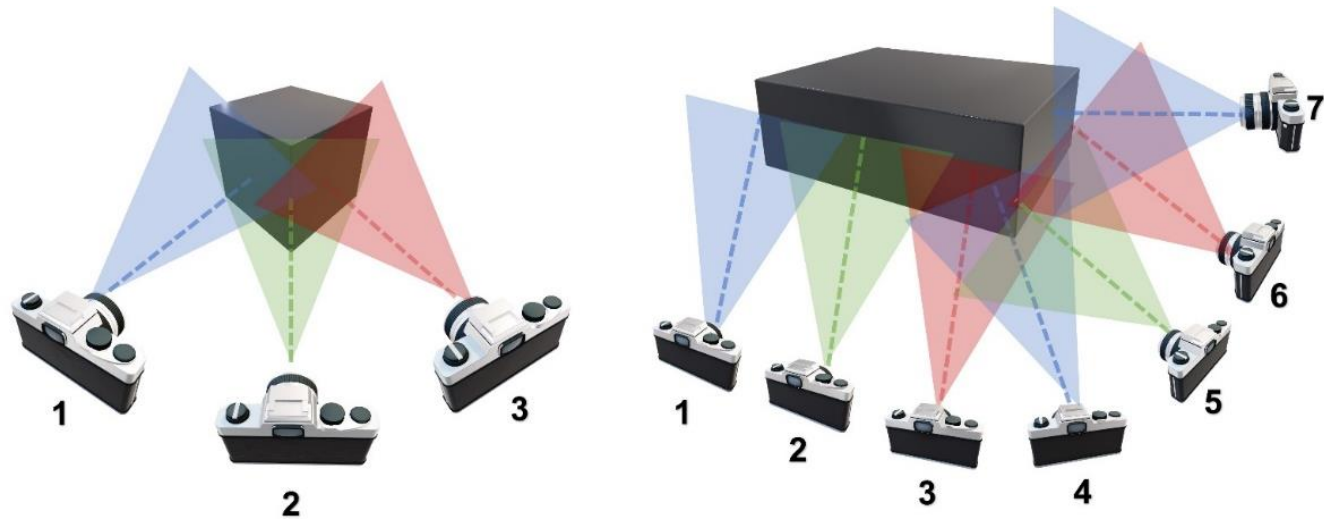

Figure 2. System of convergent taking of images for close-range photogrammetry

In this study, a total of 9 images were taken with a sufficient overlapping ratio, covering the historical building completely. The images were taken using the Huawei Mate 10 Lite android device shown in Table 1.

Table 1. Huawei Mate 10 Lite smartphone camera features

\begin{tabular}{ll}
\hline Parameters & Value \\
\hline Focal length & $27 \mathrm{~mm}$ \\
Aperture & 2,20 \\
Sensor size & $18.46 \times 27.69 \mathrm{~mm}$ \\
Amount of pixels & $16 \mathrm{MP}$ \\
Weight & $164 \mathrm{gr}$ \\
Dimension & $156 \times 75 \times 7.5 \mathrm{~mm}$ \\
\hline
\end{tabular}

Planned geodetic measurement and photography should be done in order to make 3D modeling with the digital photogrammetric method. For geodetic measurement of control points on ancient artifacts to be used in the photogrammetric evaluation, first of all, a geodetic network that completely covers the object in all aspects should be established in such terrestrial photogrammetric and modeling studies. In this context, a geodetic network has been established in the local coordinate system that will completely cover the historical structure from all sides. When choosing the control points where the measuring device will be installed, locations that will see the structure fully are preferred. Considering the physical properties of the building surface, attention was paid to the selection of sharp lines and clear control points (Uysal et al., 2015). The Cygnus Topcon KS-102 reflectorless total-station was used to mark the closed polygon mesh and control points (Figure 3).

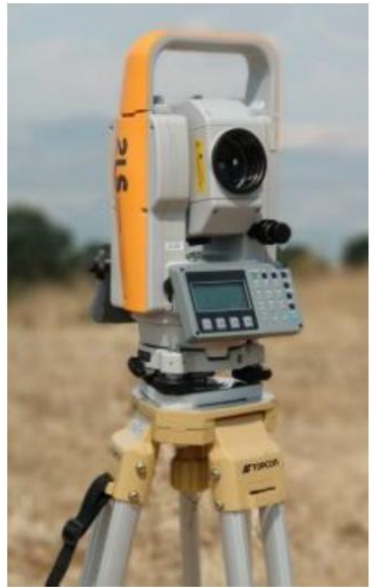

Figure 3. Cygnus Topcon KS-102 total-station

A closed polygon network was then established around the building, a total of 40 control points has been marked. For detail points, both target marks and points with natural sharp lines and characteristic features of the object were preferred. These data were primarily provided for reference in the process of merging the photographs in the software. In addition, these detail points are needed in order to examine the position accuracy of the points. 40 homogeneously distributed detail points were determined on the structure. Twentyfour of these points are marked for use in coordinating the 3D model, and 16 for accuracy analysis. After the measurement process was completed in the field, photography was done. Care has been taken to take the images with an overlay so that they can see the object from different angles. The workflow diagram of the basic workflow and Close-range photogrammetry technique used in the study for digital documentation is given in Figure 4. 

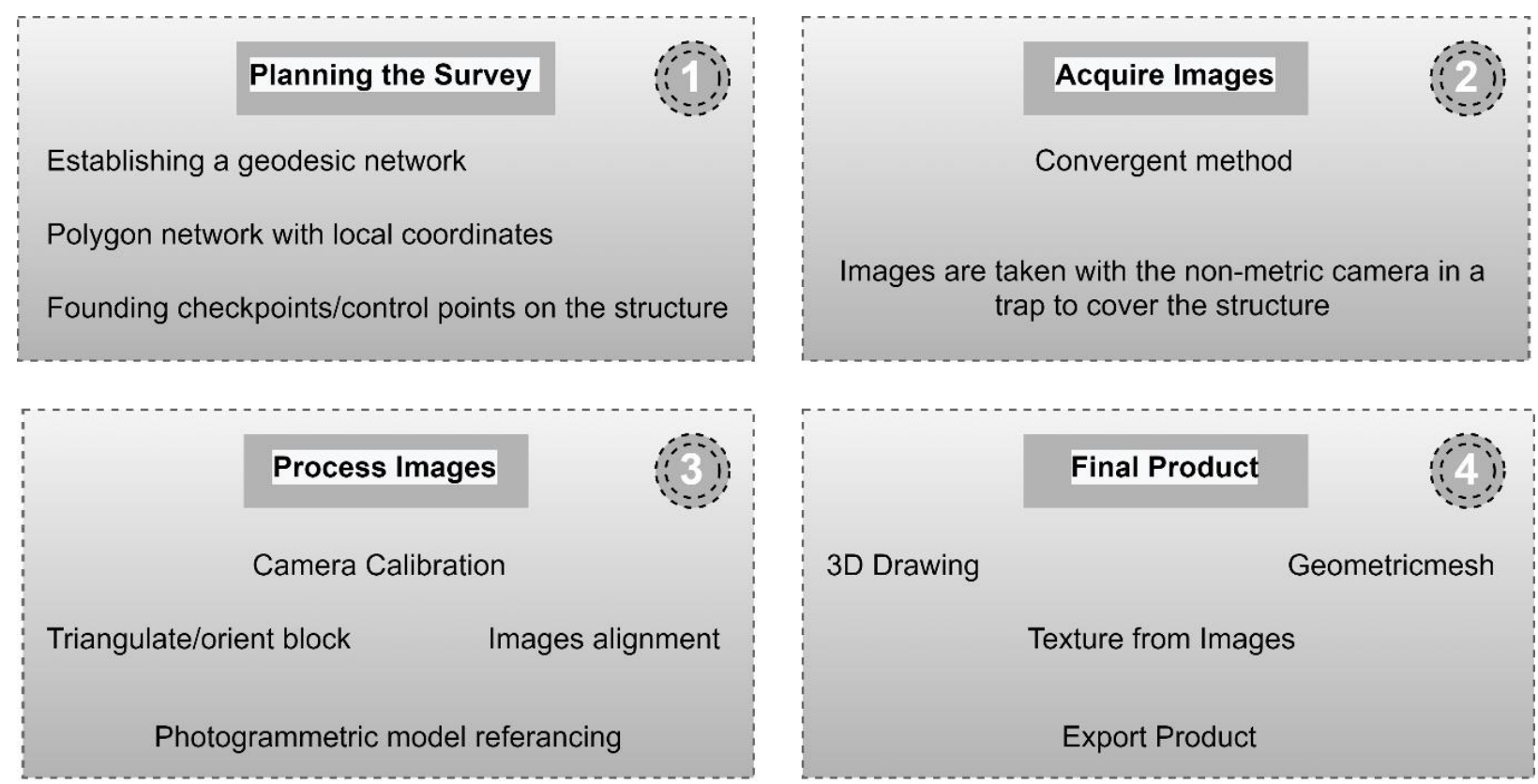

Figure 4. Basic workflow for Close-range Photogrammetry

The images and control points of the historical structure obtained as a result of the field studies were transferred to the PhotoModeler UAS software for digital evaluation. Since PhotoModeler software can perform mutual and absolute orientation at the same time, control points appearing in two or more images are marked (Yastikl,, 2013). After marking the checkpoints, one photograph was chosen as a reference and the other marked photographs were for the match of each checkpoint. Next, routing was done according to the package method in PhotoModeler software. After the orientation process, 3D model production started. Finally, texture data was added to the completed 3D model and the documentation of the historical building was completed.
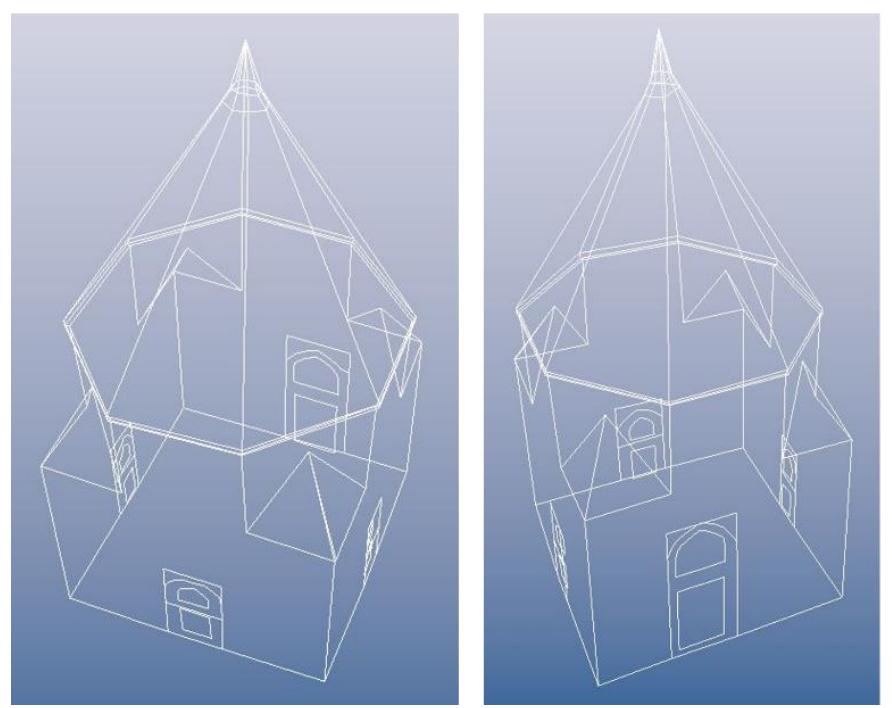

Figure 5. View of 3D Detail Drawing

By using these drawings as the basic skeleton, a solid model of the structure was covered (Figure 6). Finally, the surface of the solid model was dressed by

\section{Results}

In the Photomodeler software, 9 ground-based photographs and 40 detail points were used with the non-metric camera on the smartphone. First, the photo and detail point data of the structure were introduced to the software. Detail points were manually marked on the photographs to be used, and merging and balancing were performed. After balancing the photographs, a 3dimensional drawing of the basic skeleton of the building was obtained by drawing each detail one by one (Figure 5).
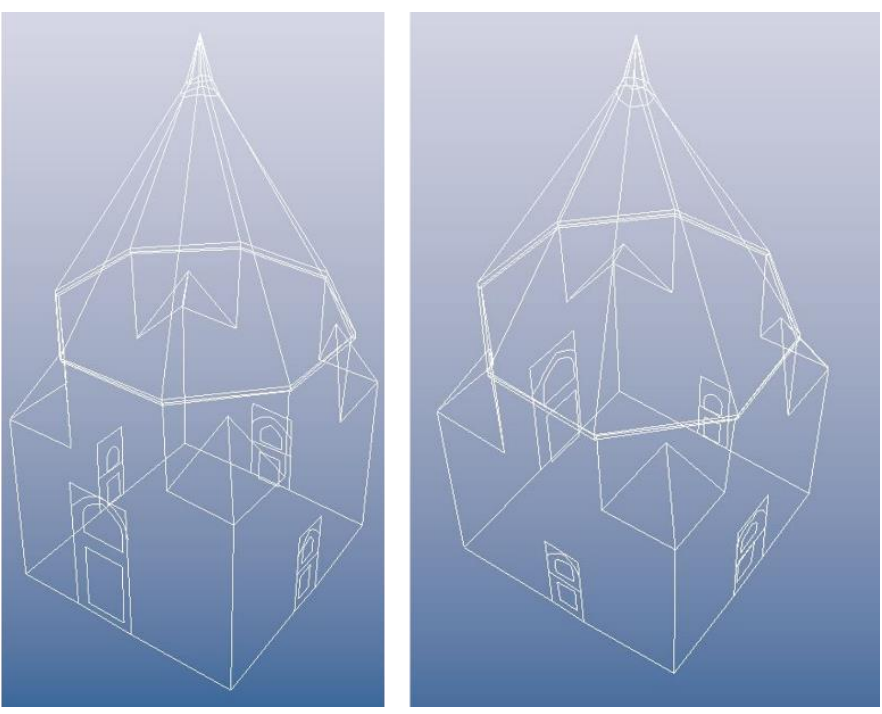

means of photographs taken from the field, and a 3D model of the structure was textured (Figure 7). 

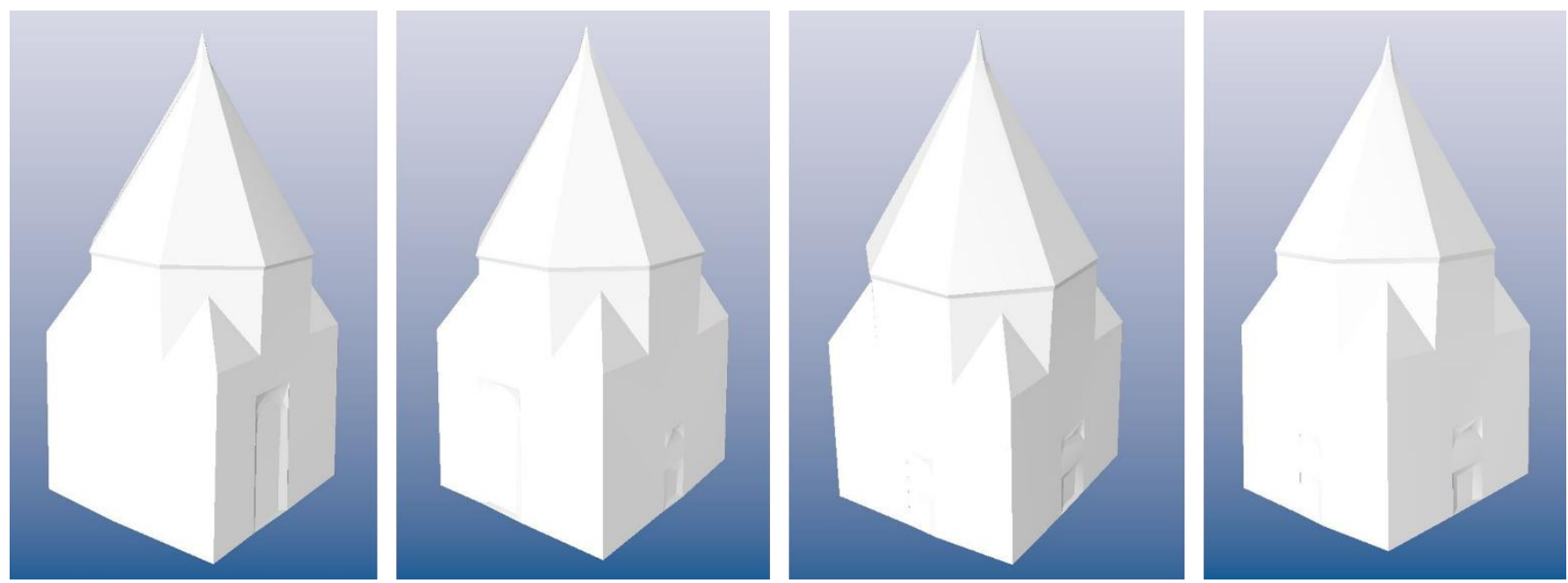

Figure 6. 3D Solid model
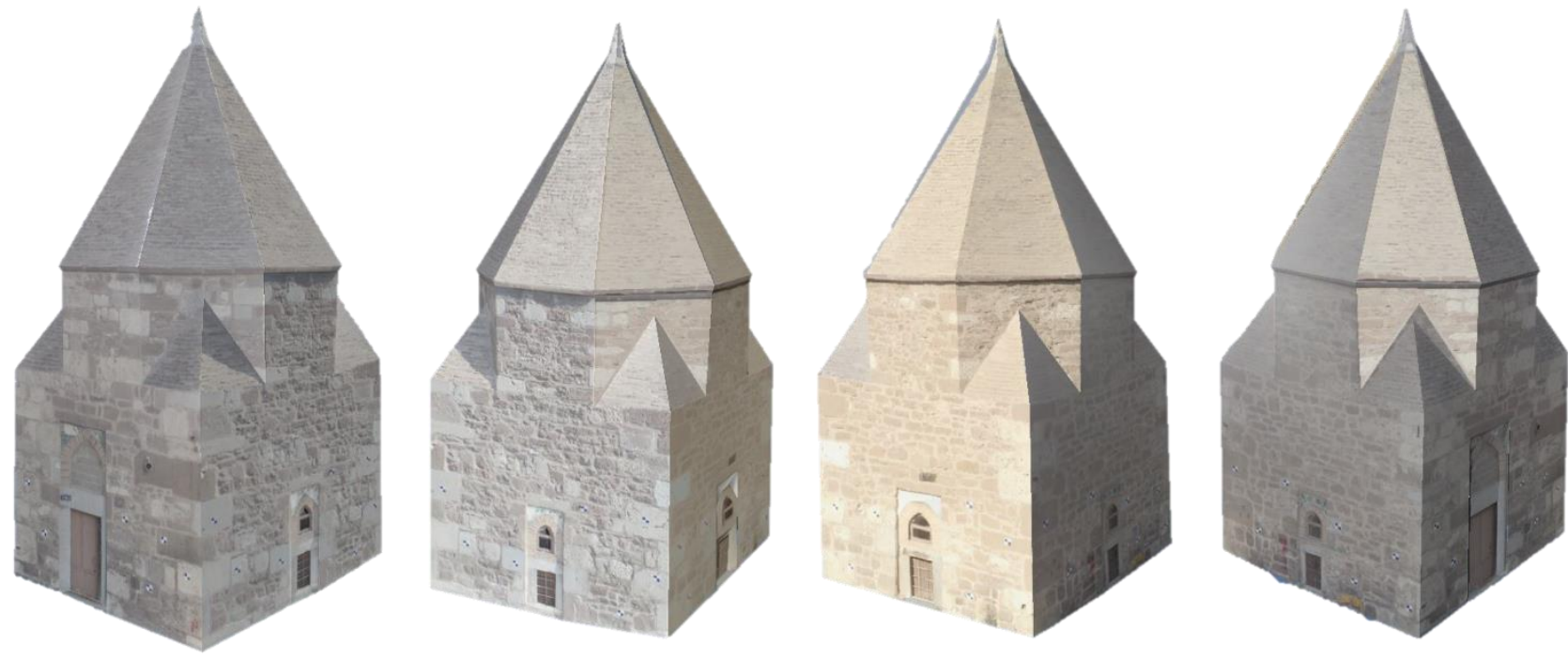

Figure 7. 3D photorealistic model view of Fakih Dede Tomb

Accuracy analysis was performed to detect the positional error for the 3D model obtained. For this process, the field coordinates obtained with the totalstation measuring instrument and the test data obtained from the 3D model were evaluated. The coordinates taken with the measuring tool were accepted as the exact coordinates. By calculating the exact value and the value differences on the model, the mean square errors of the points in the $\mathrm{x}, \mathrm{y}, \mathrm{z}$ direction were calculated.

Detail points are needed to examine the position accuracy of the points. 40 homogeneously distributed detail points were determined on the structure (Figure 8). 16 of these points were used for accuracy analysis.

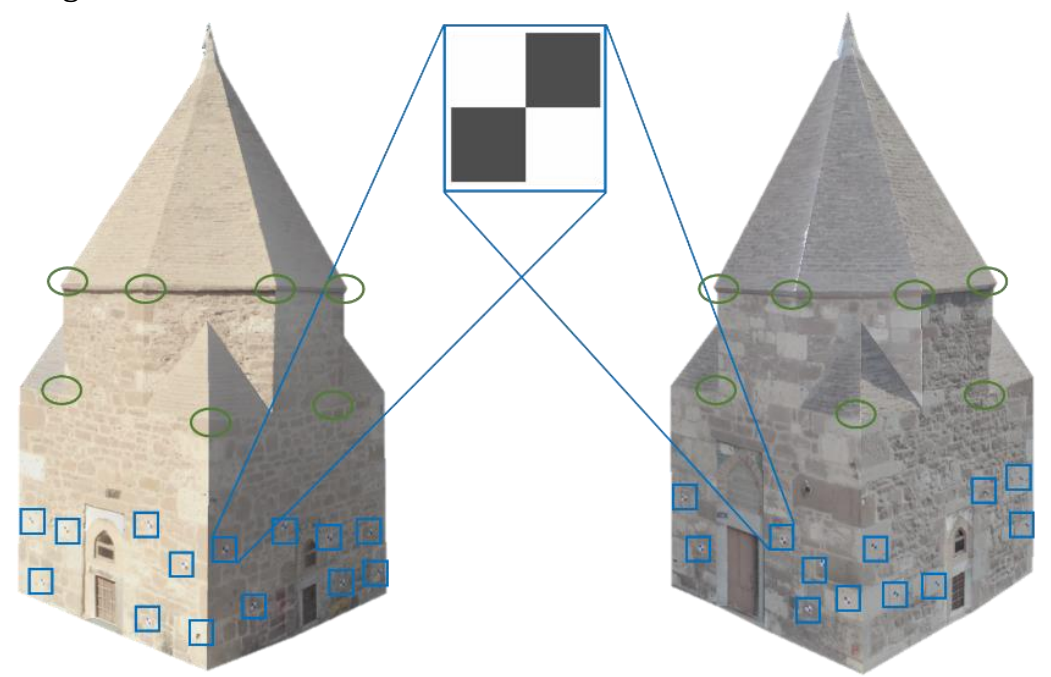

Figure 8. Display of control points used for photogrammetric process and accuracy analysis. The blue rectangles represent the paper target, and the green circles represent the distinctive characteristic points. 
Table 2. Accuracy analysis of Control points

\begin{tabular}{|c|c|c|c|c|c|c|c|}
\hline \multirow{2}{*}{$\begin{array}{c}\text { Point } \\
\text { Number }\end{array}$} & \multicolumn{3}{|c|}{ Vi (mm) } & \multicolumn{4}{|c|}{ Vi (mm) } \\
\hline & VxVx & VyVy & VzVz & Point N. & VxVx & VyVy & VzVz \\
\hline 1 & 15 & 9 & 7 & 9 & 11 & 9 & -12 \\
\hline 2 & -14 & 0 & 0 & 10 & -6 & -5 & 18 \\
\hline 3 & 3 & 2 & 4 & 11 & 9 & -16 & 9 \\
\hline 4 & -4 & -18 & 4 & 12 & -8 & -10 & 15 \\
\hline 5 & -8 & -6 & -16 & 13 & 8 & -4 & -5 \\
\hline 6 & 14 & 23 & -13 & 14 & -1 & 2 & 1 \\
\hline 7 & -4 & 12 & 18 & 15 & -16 & 4 & 0 \\
\hline 8 & -10 & 13 & 15 & 16 & -12 & 13 & -16 \\
\hline
\end{tabular}

The spatial accuracy of the control points was calculated according to equation 1, taking into account the differences (vi) and the number of measures (n). The differences between the coordinate values measured by geodetic methods of 16 points reserved for accuracy analysis and the coordinate values read on the 3D model are presented in Table 2.

$$
m X_{0}=\sqrt{\frac{V_{x} V_{x}}{n-1}}, m Y_{0}=\sqrt{\frac{V_{y} V_{y}}{n-1}}, m Z_{0}=\sqrt{\frac{V_{z} V_{z}}{n-1}}
$$

When Table 2 is examined, it is seen that the 3D model is generally produced with high precision. The reason for the high error values in the partial axes of some points is thought to be due to the fact that the overlay ratios in the photographs are not constant and vary.

In addition, for the $\mathrm{X}, \mathrm{Y}, \mathrm{Z}$ position accuracy of the obtained model, $\mathrm{mx}, \mathrm{my}, \mathrm{mz}$ were calculated as 10.29 , $11.41,11.86 \mathrm{~mm}$, respectively. If the position of the model is correct, it is calculated according to equation 2 and it is $\pm 1.94 \mathrm{~cm}$.

$$
m_{x y z}=\sqrt{m X_{0}+m Y_{0}+m Z_{0}}
$$

\section{Conclusion}

It is advantageous to use photogrammetric methods instead of traditional methods that require timeconsuming and laborious measurements in the documentation of historical artifacts. However, photogrammetric methods have disadvantages such as expensive measuring instruments, high-dimensional data, and complex modeling processes.

In this study, the performance of photogrammetric methods in the documentation of historical artifacts by using non-metric cameras such as smartphones, which we use frequently in our daily life and which can be accessed more easily than alternatives, has been examined.

In order to examine the accuracy of the work, the differences between the control points and detail points measured with the total station were calculated and the precision of the model was found to be $\pm 1.94 \mathrm{~cm}$. Yakar and Bilgi (2020) study history by using mobile phones in III. They made 3D documentation of Ahmet Fountain. In their study, they found the 3D position accuracy to be $\pm 2.56 \mathrm{~cm}$.
It has been seen that the 3D model obtained in line with this study and the work done by Yakar and Bilgi can be used as a base for the documentation and protection of cultural heritage. These models play an important role in the restoration works, in determining the deformations that will occur on the historical artifacts and in monitoring the changes that occur on the artifacts in question. On the other hand, it is thought that mobile phones can contribute to the documentation of many cultural heritage works, especially since they have a large user base and their use does not require expertise.

\section{Author contributions}

Mustafa Emre Döş: Conceptualization, Methodology, Software, Analysis; Abdurahman Yasin Yiğit: Data acquisition, Writing, Original draft preparation, Software, Validation, Visualization; Murat Uysal: Investigation, Writing-Reviewing and Editing.

\section{Conflicts of interest}

The authors declare no conflicts of interest.

\section{References}

Akman O., Bayramog̃lu N., Aydin Alatan A., Jonker P. (2010). Utilization of Spatial Information for Point Cloud Segmentation, 3DTV-Conference 2010: The True Vision - Capture. Transmission and Display of 3D Video, DOI: 10.1109/3DTV.2010.5506339.

Al-kheder S, Al-shawabkeh Y \& Haala N (2009). Developing a documentation system for desert palaces in Jordan using 3D laser scanning and digital photogrammetry. In Journal of Archaeological Science, 36, 537-546.

Alptekin A \& Yakar M (2020). Mersin Akyar Falezi'nin 3B modeli. Turkey Lidar Journal, 2(1), 5-9.

Alptekin A, Fidan Ş, Karabacak A, Çelik M Ö \& Yakar M (2019). Üçayak Örenyeri'nin yersel lazer tarayıcı kullanılarak modellenmesi. Turkey Lidar Journal, $1(1), 16-20$.

Apollonio F I, Fantini F, Garagnani S \& Gaiani M (2021). A Photogrammerty-Based Workflow for the Accurate 3D Construction and Visualization of Museums Assests. In Remote Sensing, 13(3).

Arias P, Ordóñez C, Lorenzo H \& Herraez J (2006). Methods for documenting historical agro-industrial buildings: a comparative study and a simple 
photogrammetric method. In Journal of Cultural Heritage, 7, 350-354.

Asri İ \& Çorumluoğlu Ö (2007). Büyük Objelerde Tarihi Dokümantasyon ve Tanıtım Amaçlı Gpssit Destekli Digital Fotogrametrik 3B Modelleme. TUFUAB IV. Teknik Sempozyumu, İstanbul.

Asri İ \& Çorumluoğlu Ö (2014). Tarihi yerleşim alanlarının yersel fotogrametri yöntemi ile $3 \mathrm{~b}$ modellenmesi: Santa harabeleri örneği, Uzaktan Algılama-CBS Sempozyumu (UZAL-CBS 2014), İstanbul, 1-8.

Castellini P, Abaskin V \& Achimova E, (2007). Portable electronic speckle interferometry device for the damages measurements in veneered wood artworks. Journal of Cultural Heritage, 9, 225-233.

Chandler J H, Bryan P \& Fryer J G (2007). The development and application of a simple methodology for recording rock art using consumer-grade digital cameras. In Photogrammetric Record, 22, 10-21.

Di Angelo L, Di Stefano P, Guardiani E \& Morabito A E M (2021). A 3D Informational Database for Automatic Archiving of Archaeological Pottery Finds. In Sensors, 21(3).

Donato E \& Giuffrida D (2019). Combined Methodologies for the Survey and Documentation of Historical Buildings: The Castle of Scalea (CS, Italy). In Heritage 2019, 2, 2384-2397.

Gruen A \& Akca D (2005). Least squares 3D surface and curve matching. In ISPRS Journal of Photogrammetry and Remote Sensing, 59, 151-174.

Guarnieri A, Remondino F \& Vettore A (2006). Digital Photogrammetry and TLS Data Fusion Applied to Cultural Heritage 3D Modeling. ISPRS Commission V Symposium, Image Engineering and Vision Metrologhy, September 25-27, 2006, Dresten, Germany.

Kaya Y, Polat N, Şenol H İ, Memduhoğlu A \& Ulukavak M (2021). Arkeolojik kalıntıların belgelenmesinde yersel ve İHA fotogrametrisinin birlikte kullanımı. Türkiye Fotogrametri Dergisi, 3 (1), 9-14. DOI: 10.53030/tufod.899089

Korumaz A G, Dülgerler O N \& Yakar M (2011). Kültürel Mirasin Belgelenmesinde Dijital Yaklaşimlar. Selçuk Üniversitesi Mühendislik, Bilim ve Teknoloji Dergisi, 26(3), 67-83.

Kuçak R A, Kiliç F \& Kisa A (2016). Analysıs of Terrestrıal Laser Scanning and Photogrammetry Data For Documentation of Historical Artifacts. Int. Arch. Photogramm. Remote Sens. Spatial Inf. Sci., Xlı2/W1,155-158,Https://Doi.Org/10.5194/İsprsArchives-Xlil-2-W1-155-2016, 2016.

López-Aparicio S \& Grašiene R (2013) Screening indoor air quality evaluation in the Lithuanian theatre, music and cinema museum. Journal of Environmental Engineering and Landscape Management. 21, 52-58.

Martínez S, Ortiz J, Gil M L, Rego M T (2013). Recording complex structures using close range photogrammetry: The cathedral of Santiago de Compostela. In Photogrammetric Record, 28, 375395.
Ozimek A, Ozimek P, Skabek K \& Labedz P (2021). Digital Modelling and Accuracy Verification of a Complex Architectural Object Based on Photogrammetric Reconstruction. In Buildings 11(5).

Pesci A, Teza G, Bonali E, Casula G \& Boschy E (2013). A laser scanning-based method for fast estimation of seismic-induced building deformation. In ISPRS Journal of Photogrammetric and Remote Sensing, 79, 185-198.

Polat N, Çokoğullu S, Memduhoğlu A, Ulukavak M, Şenol H İ, Oral M, Karaçizmeli M \& Marangoz Ö (2021b). İha Fotogrametrisinin Arkeolojik Yüzey Araştirmalarina Katkilarinin İncelenmesi. TÜBA-AR Türkiye Bilimler Akademisi Arkeoloji Dergisi, (28), 175-186. DOI: 10.22520/tubaar.2021.28.009

Polat N, Önal M, Kaya Y, Memduhoğlu A, Kaya N, Ulukavak M, Mutlu S \& Mutlu S (2021a). Harran Ören Yeri Kazısında Bulunan kabartma Yazıların Üç Boyutlu Olarak Modellenmesi. Bitlis Eren Üniversitesi Fen Bilimleri Dergisi, 10 (2), 594-601. DOI: 10.17798/bitlisfen.881781

Reinoso-Gordo J F, Gámiz-Gordo A \& Barrero-Ortega P (2021). Digital Graphic Documentation and Architectural Heritage: Deformations in a 16thCentury Ceiling of the Pinelo Palace in Seville (Spain). In ISPRS Int. J. Geo-Inf. 2021, 10, 85.

Remondino F (2011). Heritage recording and 3D modeling with photogrammetry and 3D scanning. In Remote Sensing, 3, 1104-1138.

Şaman-Doğan N (2009). An Architectural Monument from Karamanoğlu Period: The Mausoleum of Fakih Dede in Konya. In Hacettepe University Journal of Turkic Studies, 11(1), 91-108.

Şenol H İ, Memduhoglu A \& Ulukavak M (2020). Multi instrumental documentation and 3D modelling of an archaeological site: a case study in Kizilkoyun Necropolis Area. Dicle Üniversitesi Mühendislik Fakültesi Mühendislik Dergisi, 11 (3), 1241-1250. DOI: 10.24012 /dumf.801662

Şenol H İ, Polat N, Kaya Y, Memduhoğlu A \& Ulukavak M (2021). Digital documentation of ancient stone carving in Şuayip City. Mersin Photogrammetry Journal, 3 (1), 10-14. DOI: 10.53093/mephoj.899157

Skabek K \& Tomaka A (2014). Comparison of photogrammetric techniques for surface reconstruction from images to reconstruction from laser scanning. Theor. Appl. Informat. 2014, 26, 161178.

Sužiedelyte-Visockiene J, Kumetaitiene A \& Bagdžiunaite R (2011). Accuracy analysis of different surface reconstruction modelling methods for heritage objects digitized considering photogrammetric data. In Geodesy and Cartography, 37, 56-62.

Suziedelyte-Visockiene J, Bagdziunaite R, Malys N \& Maliene V. (2015). Close-Range Photogrammetry Enables Documentation of Environment-Induced Deformation of Architectural Heritage. In Environmental Engineering and Management Journal, 14 (6). Pp. 1371-1381. Issn 1582-9596

Tapete D, Casagli N, Guido L \& Riccadro F (2013). Integrating radar and laser-based remote sensing techniques for monitoring structural deformation of 
archaeological heritage. In Journal of Archaeological Science, 40, 176-189.

Uysal M, Uslu A, Toprak A S \& Polat N (2015). Menagas Pebble Stele Sample in Modeling 3 By Archaeological Photogrammetric Method. TUFUAB VIII. Technical Symposium, pp: 252-254, Konya, Turkey.

Varas-Muriel M J, Fort R, Martínez-Garrido M I, ZornozaIndart A \& López-Arce P (2014). Fluctuations in the indoor environment in Spanish rural churches and their effects on heritage conservation: Hygrothermal and $\mathrm{CO} 2$ conditions monitoring. Building and Environment. 82, 97-109.

Yakar İ \& Bilgi S (2019). Mobil Telefonlar Kullanılarak Elde Edilen 3 Boyutlu Modellerin Kültürel Mirasın Korunması Kapsamında Kullanılabilirliği: Iı. Ahmet Çeşmesi Örneği. Türkiye Fotogrametri Dergisi, 1(1), 25-29.

Yakar M, Orhan O, Ulvi A, Yiğit A Y \& Yüzer M M (2015). Sahip Ata Külliyesi Rölöve Örneği. TMMOB Harita ve Kadastro Mühendisleri Odası, 10.
Yakar M, Yıldız, F \& Yılmaz H M (2005). Tarihi Ve Kültürel Miraslarin Belgelenmesinde Jeodezi Fotogrametri Mühendislerinin Rolü. TMMOB Harita ve Kadastro Mühendisleri Odası, 10.

Yakar M, Yılmaz H M \& Mutluoğlu Ö (2010). Comparative evaluation of excavation volume by TLS and total topographic station-based methods. Lasers in Eng,19, 331-345.

Yastikli N (2007). Documentation of cultural heritage using digital photogrammetry and laser scanning. In Journal of Cultural Heritage, 8, 423-427.

Yastıklı N (2014). Reverse Engineering Engineering Application of Earthly Photogrammetry. UZAL-CBS Symposium, İstanbul, Turkey.

Yılmaz H M, Karabörk H \& Yakar M (2000). Yersel Fotogrametrinin Kullanim Alanlari. Niğde Üniversitesi Mühendislik Bilimleri Dergisi 4 (1), 1 